\title{
China’s New Long March—Economy Development Transition
}

\author{
ZHOU Yu-feng \\ Chongqing Medical University, Chongqing, China
}

\begin{abstract}
Whether and how China's rapid economic growth can be sustained, has recently become a hot topic of discussion all over the world. After 30 years of economic development, China has become an important power of world economy. Then, whether China's economy is able to sustain development and how it sustains development, will not only have relationship to the prosperity of China itself, but also influence the world economic and political future trend of international issues. This paper analyzes the necessity of China's economic transformation, path and existing problems of China's economic transformation, hoping to provide reference opinions.
\end{abstract}

Keywords: domestic and global imbalances, barriers blocking transition, well-ruled and true market economy

\section{Introduction}

As China economy has achieved remarkable growth during past 30 years, it has been a hot topic that whether and how China economy can keep its victory. When the severest global financial crisis since the Great Depression directly affects the Chinese economy, economic transition stands out as a crucial measure to surmount the turmoil and create opportunities to ensure China's sustainable economic growth. And the answer not only determines the up and down of China, but also affect the future of world, for China has become an important economy power after 30 years of development, it is a global problem.

\section{Critical Juncture for China Economy}

On February 3 of 2008, General Secretary HU Jin-tao delivered an important speech that speeding up change in the mode of economic development relations reform and opening up and socialist modernization construction and "thoroughly implement the scientific concept of development of the important objectives and strategic initiatives”. On March 5 of 2008, Premier WEN Jia-bao said that economic development transition was urgent in the government work report. Two country leaders emphasized on economic development transition at the same time, and this shows its importance.

In the view of long terms, imbalances will also weaken our financial system. If China encountered external or internal crisis, there will be a serious systemic risk. So it is urgent for China to transit the way of economy development. The global financial crisis since the middle of 2007 have exposed many hidden and deep problems in China economy, which can be attributed to both domestic and global imbalances in the view of macroeconomic (Campos \& Fidrmuc, 2005).

\section{Aggravating Domestic Imbalances}

The domestic imbalances mainly represented at investment and consumption, in other words, we invest

ZHOU Yu-feng, associate professor of economics, Management Department, Chongqing Medical University, Medicine and Social Development Research Center of Chongqing Medical University. 
too much and consume too little, and the growth rate of investment far exceeds the consumption. For example, consumption contributed for GDP growth fall from 63.8\% to 52.5\% over the period from 2000 to 2009, while investment goes up from $21.7 \%$ to $92.3 \%$ at the same time (see Table 1 ).

Table 1

The Contribution Rate of Economic Growth by Year, 2000-2009

\begin{tabular}{lcccccccccc}
\hline & 2000 & 2001 & 2002 & 2003 & 2004 & 2005 & 2006 & 2007 & 2008 & 2009 \\
\hline Investment (\%) & 21.7 & 50.1 & 48.8 & 63.7 & 55.3 & 37.7 & 42 & 38.8 & 32.3 & 92.3 \\
Consumption (\%) & 63.8 & 50 & 43.6 & 35.3 & 38.7 & 38.2 & 38.7 & 39.7 & 35.2 & 52.5 \\
Export (\%) & 14.5 & 0.1 & 7.6 & 1 & 6 & 24.1 & 19.3 & 21.5 & 32.5 & -44.8 \\
\hline
\end{tabular}

Note. Source: Notice of the Chinese national bureau of statistics.

This led to a series of social problems such as excess capacity, lack of consumption, gap in income. For example, China ranked first in steel (about half of world production), cement (also about half), aluminum (about 40\%), and glass (31\%). The country topped the US in auto production in 2009, and remains second only to South Korea in shipbuilding, with 36\% of global capacity. But based on the NDRC's (National Development and Reform Commission) figures, 2008 capacity utilization rates were just 76\% for steel, $75 \%$ for cement, $73 \%$ for aluminum, $88 \%$ for flat glass, $40 \%$ for methanol, and $20 \%$ for poly-crystalline silicon. There is serious excess capacity in a wide variety of sectors (JIA, 2009).

China's income gap is widening. According to the latest report from the World Bank, China's wealth concentration has by far exceeded that of the US with 1 percent of the Chinese families being accountable for 41.4 percent of the country's entire wealth. China is also the country with the largest income disparity in the world. China's Gini Index, a gauge of income gap, has reached 0.47 (and rising) in 2009 from the 0.28, 30 years ago. 0.4 percent is considered a "warning line". Exceeding this mark signifies that the biggest pieces of the wealth cake are being taken by the minority. Now, the incomes of the residents in urban areas are 3.3 times those in the rural areas, the highest wages are 15 times those of minimum wages. Senior managers in listed firms see their wages 18 times than of workers in the first line. The salaries of senior managers in State-owned enterprises (SOEs) are 128 times than average.

\section{Increased Global Imbalances}

The global imbalances represented as the vast trade surplus and fast increased foreign exchange reserves. Indeed, the most fractious issue in China's international economic relations in recent years has been its bilateral trade imbalances, especially with the United States and Europe. China's reserves, which have been the world's largest, reached over 20.34 trillion Yuan in April of 2010.

China's global imbalances heightened trade frictions and worse trade condition between China and other country (see Table 2). The US imbalance with China is of such concern that US lawmakers have proposed levying punitive new tariffs against imports from China as a means of reducing the US deficit. China was also the most frequent subject of anti-dumping investigations in the WTO, there totaled 677 anti-dumping investigations targeted China since 1995-2008, rather than 252 cases of South Korea.

At the same time, the prices of our exported products were compressed, resources were wasted and environment were damaged. And excess liquidity comes with imbalances, which causes asset bubbles and inflation. Market of real estate, stocks and collectibles becomes overheated and CPI raises rapidly. This problem has been a realistic risk that everyone can felt. 
Table 2

China Trade Surplus Statistics With U.S.

\begin{tabular}{|c|c|c|}
\hline Year & Statistics supplied by China & Statistics supplied by U.S. \\
\hline 1979 & -12.7 & -10.7 \\
\hline 1981 & -28.7 & -15.4 \\
\hline 1982 & -21 & -4.1 \\
\hline 1983 & -6.1 & 3.2 \\
\hline 1984 & -14.5 & 3.8 \\
\hline 1985 & -17.5 & 0.6 \\
\hline 1986 & -20.9 & 16.6 \\
\hline 1987 & -18 & 27.9 \\
\hline 1988 & -32.5 & 34.7 \\
\hline 1989 & -38.5 & 61.8 \\
\hline 1990 & -14.1 & 104.1 \\
\hline 1991 & -18.5 & 126.9 \\
\hline 1992 & -3.1 & 182.6 \\
\hline 1993 & 62.7 & 227.7 \\
\hline 1994 & 74.9 & 294.9 \\
\hline 1995 & 85.9 & 338.1 \\
\hline 1996 & 105.3 & 395.2 \\
\hline 1997 & 164 & 497.5 \\
\hline 1998 & 210.2 & 569 \\
\hline 1999 & 224.7 & 686.7 \\
\hline 2000 & 297.4 & 838.1 \\
\hline 2001 & 280.8 & 830.5 \\
\hline 2002 & 427.2 & 1,030.6 \\
\hline 2003 & 586.1 & $1,240.7$ \\
\hline 2004 & 802.7 & $1,619.4$ \\
\hline 2005 & 1,141.7 & $2,015.5$ \\
\hline 2006 & 1,442.6 & 2,325.5 \\
\hline 2007 & 1,633 & 2,562 \\
\hline 2008 & 1,708.6 & 2,663.3 \\
\hline
\end{tabular}

Note. All figures are in 100 millions of U.S. dollars.

\section{Transition's Barriers Analysis}

The cause of imbalance of China economy is distorted development approach which driven by vast investment and export. The only way to solve the imbalance problem is to transform development approach: from extensive growth to technological innovation, and from over-reliance on exports to boost domestic demand. It has been 14 years since actively promoting the shift of economic growth model was proposed at Government Work Report in 1996, and emphasized each year. But unfortunately, it has not effectiveness, so it is necessary to make an in-depth analysis of the barriers obstructing the transform of economy.

\section{Excessive Government Intervention}

Firstly, the predominant mode of ownership of enterprise is public in China and all levels of government 
still have important influence to company, no matter state owned or private owned. Government allocates important resource such as bank loan and land. For instance, bank was forced to loan to poor performance company, and only government can acquire cheap lands from peasants, and then sold it to real estate firm at expensive price.

On the other hand, market forces are greatly suppressed by government. The price of land, capital, labor and other production factors is not decided by market but by government. Government has a trend to depress the price, which led to a waste of resources for production. This leads to inefficiency. When considering investment efficiency in macroeconomic terms, the "incremental capital—output ratio (ICOR)" serves as a guide. ICOR is obtained by dividing the ratio of investment to GDP with real economic growth, and the smaller it is, the more efficient the investment is. China's average ICOR for the last 30 years was 4.1, which was comparatively higher.

\section{GDP Worship}

Secondly, growth rate of GDP was chosen to qualify the performance of government, so it is hard for government to scarify short term benefit to change development way. On the contrary, people's livelihood, quality of growth, green development should become the key words. GDP measures the total income of a country, it refers to the market prices of all resident units of a country in a given period all production activities (including products and services) of the final result, all sectors of national economy increased in the accounting period the sum of (the new industry to create value and the value of fixed assets and transfer). It is the most common core of economic indicators, a measure of the national economy overall activity indicators, without this indicators of GDP accounting, we can not reflect a country and regional production scale and industrial structure, the scale of demand, can not to judge a country's economy and its business cycle, can not provide the economic basis for the health of the most important (LENG, 2009)

But GDP is not God, not omnipotent. GDP can not measure everything. In 1968, U.S. Senator Robert Kennedy ran for president, has criticized that "GDP does not take into account the health of our children, and their quality of education, or their games fun. It also does not include the beauty of our poetry or the marriage stability, not including our debate on public issues, the wisdom or integrity of our civil servants. It does not measure our courage, but our wisdom. There is no measure of our love for the motherland. In short, it measures everything, but not includes our life meaningful”.

\section{Obstruction From Special Interest Groups}

Special interest groups exist in almost all the fields and have links with corrupt officials. From the constant failures to check rising housing prices and rampant speculation in the market to public hearings predictably ending in still higher prices all point to one thing: special interest groups' attempt to manipulate public policies in their own favor. They operate mostly underground to extract privileges, which leads to corruption in the government and intensifies social contradictions.

There are three kinds of special interest groups in China: monopoly capital, international capital and domestic private capital. Monopoly capital is represented by state-owned enterprises and monopoly enterprises backed by the government. The administrative-organs-turned industry leaders such as those in the power, postal service, railway, oil and telecom sectors have thwarted true development by monopolizing or using their administrative influence on these sectors. They make huge profits but little of that goes to the government.

The existence of interest groups in a market economy is normal. They pursue a set of interests, as well as 
create social wealth. But the trouble is that in China they have been popping up only to snatch away other people's or group's interests by building official-businessperson and power-money nexus.

\section{Suggested Solution for Transition}

After the reasons of imbalance were analyzed, it is clear for us how to solve the problem. A well-ruled and true market economy must be formed and influences left by traditional mechanisms must be wiped out.

\section{Establish Rule of Law}

First of all, rule of law must be established, which is the basis of market economy. A 1997 World Bank report claimed that "Country with stable government, predictable methods of changing laws, secure property rights, and a strong judiciary saw higher investment and growth than countries lacking these institutions".

It is necessary and effective measures to deal with the crisis and revive the economy as soon as possible are needed. However, it does not mean one says "no" to the market. On the contrary, only if the policies led by the government are embedded in the market can they act as a pump to refresh the market. We must push forward reform and opening up unswervingly and make market play its role in resource allocation. Many difficulties encountered are caused by incomplete reform, rather than market-oriented reform (WANG, 2003).

The role of market must be recognized and government interventions must be stopped. In the financial crisis, with the shrinking world market and the diving global economy, the idea of an omnipotent market comes under scrutiny. Policies including government guidance, fiscal stimulus, and employment subsidies are widely applied around the globe. The monopoly must be broken and administrative interference must be eliminated.

\section{Adjust the Distribution of Income}

It is the key point to decided success or failure of economy development transition. For instance, the poor are forced to save because of deterioration in access to health care, education, and social security. Thus, if China wants to increase consumption as a driver of economic growth, it has to reduce income equality, improve social services, and provide social safety nets for the population.

For the vast majority of low-income people, the labor income is their most important source of income, even wealth, most people's only source of income. When the labor share of income distribution as a whole is too low, it will surely lead to the vast majority of the residents are very low income levels, consumption, capacity to pay small.

Government should speed up the adjustment of national income distribution structure, gradually raise the income distribution in the national income share of labor remuneration in the proportion of the initial distribution, increase the tax on the income distribution of the regulatory role, and deepen the reform of the income distribution system of monopoly industries, and further standardize income distribution order; pairs of urban and rural low-income people in financial difficulties to give more care to protect the good of their basic life and basic rights and interests continue to focus on poverty alleviation.

\section{Promote Technology Innovation}

Science and technology plays great role to overcome the financial crisis and promoting economic recovery. We must pay close attention to planning post-crisis development of technology, to new energy, biotechnology, space technology and other aspects of high-end research and development, in order to support sustainable economic development powers. Bill Gates had ever said, the 21st century is the century of network but 21st century is green and low carbon century. Through investing in technologies and technology innovation, China 
is expected to reduce its oil imports by up to 30 to 40 percent, its coal demand by 40 percent and greenhouse gas emission by 50 percent by 2030 .

But mechanism of technology innovation must be reformed at first. We must speed up to build a business-oriented and market-oriented production and research combining technical innovation system, give full play to institutions of higher learning and scientific research institutes in technological innovation. While overall statistics show that enterprises now account for close to three-quarters of China's R\&D expenditures, in reality, they have allocated few financial resources to carry out innovative R\&D activities. Companies that do spend heavily on R\&D—such as Huawei and ZTE, telecommunication equipment makers, and BYD, a battery maker turned hybrid and electric automobile manufacturer-are the outliers, not the norm.

\section{References}

Campos, N. F., \& Fidrmuc, J. (2005, November 10). Political economy of transition and development: Institutions, politics and policies (1st ed.). London.

JIA, K. (2009, November, 25). News analysis: U.S. economy on long transition to recovery. Retrieved from www.chinaview.cn

LENG, J. (2009, September 18). Corporate governance and financial reform in China's transition economy. Hong Kong: Hong Kong University Press.

WANG, H. (2003, November, 28). China's new order: Society, politics, and economy in transition. London, Harvard University Press. 